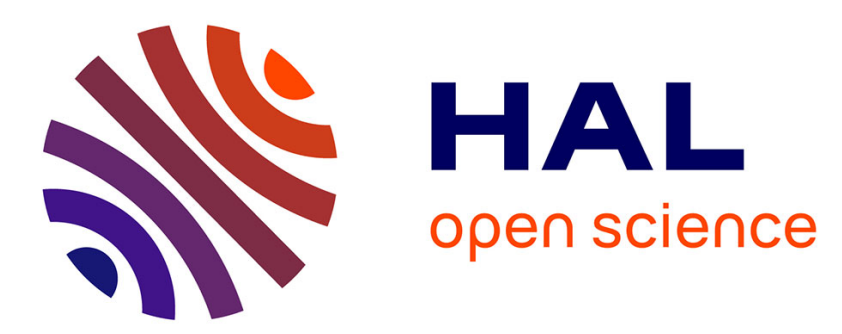

\title{
Building and defending the alternative Internet: the birth of the digital rights movement in France
}

\author{
Patrick Pétin, Félix Tréguer
}

\section{To cite this version:}

Patrick Pétin, Félix Tréguer. Building and defending the alternative Internet: the birth of the digital rights movement in France. Internet histories, 2018, pp.1-18. 10.1080/24701475.2018.1521059 . halshs-01944441v2

\section{HAL Id: halshs-01944441 \\ https://shs.hal.science/halshs-01944441v2}

Submitted on 27 Feb 2019

HAL is a multi-disciplinary open access archive for the deposit and dissemination of scientific research documents, whether they are published or not. The documents may come from teaching and research institutions in France or abroad, or from public or private research centers.
L'archive ouverte pluridisciplinaire HAL, est destinée au dépôt et à la diffusion de documents scientifiques de niveau recherche, publiés ou non, émanant des établissements d'enseignement et de recherche français ou étrangers, des laboratoires publics ou privés. 


\section{Building and Defending the Alternative Internet: The Birth of the Digital Rights Movement in France}

Author manuscript - published in "Internet Histories" vol. 2, special issue web90 (2018)

Patrick Pétin ${ }^{\mathrm{a}} \&$ Félix Tréguer ${ }^{\mathrm{b}}$

${ }^{a}$ Institut des sciences sociales du politique (ISP), Université Paris-Nanterre, France

${ }^{b}$ Institut des sciences de la communication (ISCC), CNRS, Paris, France

\section{Suggested citation:}

Pétin, Patrick, and Félix Tréguer (2018). Building and Defending the Alternative

Internet: The Birth of the Digital Rights Movement in France. Internet Histories 2(2):

1-18. https://doi.org/10.1080/24701475.2018.1521059 


\title{
Building and Defending the Alternative Internet: The Birth of the Digital Rights Movement in France
}

\begin{abstract}
In the mid-1990s, as the Internet underwent a major wave of growth and commodification, it also became increasingly politicised. In this article, we analyse the process that led to the birth of the digital rights movement in France. Based on archival work and interviews with key protagonists of the movement, this article blends historical, sociological and policy analysis to help explain the politicisation of French "Internet pioneers." It documents the emergence of alternative Internet service providers, their relationship to other activist groups, and to the wider digital economy. It then shows how the same small group of individuals turned to political advocacy by surveying some of their interactions with policy-makers, focusing in particular on the debate on intermediary liability and freedom of expression. We stress that the particular social trajectories of these digital rights activists confronted with the commodification of the Internet and the power practices of the state converged to create a "perfect storm" that led them to wield exceptional influence on Internet policy in this early phase of development. We also highlight some of the movement's internal contradictions and explain its waning influence from the early 2000s on. Through this article, we hope to help diversify the historiography of digital activism as well as to contribute to comparative-historical approaches.
\end{abstract}

Keywords: activism; alternative internet, freedom of expression, hackers.

\section{Introduction}

In 1992, a young French programmer named Valentin Lacambre had a simple yet

brilliant idea: Connecting France's public videotext system Minitel to the open plains of Usenet - the decentralized and federated system for online forum established in 1980. Two years later, his initiative expanded to the Internet, which was undergoing extraordinary growth, with a booming number of interconnected networks and connected machines (Gerich, 1992). After having successfully trademarked the name 
"Internet", France Telecom agreed to give Lacambre the Internet Minitel domain, accessible through the 3615 dial number used for commercial Minitel services (Lacambre, 1999). Now with a substantive revenue stream, Lacambre launched the website altern.org, a completely free hosting service that allowed any person with an Internet access to open her online storage space to publish websites and manage emails accounts. According to him, the Internet came with "exceptional possibilities for public expression" and these needed to be made available to all "citizens," with "no advertising" nor "commercial exploitation." In a matter of months, the user base of Altern exploded.

But from 1997 on, Lacambre faced a number of trials, becoming the target of many plaintiffs that took issue with the publications of its users and thought that Lacambre should be liable for the damages they had suffered. The idea that any citizen could join the online public sphere with no prior authorisation or ex-ante oversight of their speech upset the political balance formed around freedom of expression. As many jurisdictions in North America or Europe grappled with difficult debates on "intermediary liability," Altern would become the focal point of this controversy in France. In 1999, an appellate court eventually held Lacambre liable for the content of its users because it gave them a free and allegedly anonymous channel to broadcast their voices. Appalled by the notion that he should verify the identity of its users and monitor their publications, the young man took a radical decision. Rather than accepting to play the role of a private censor something he could not nor would not do -, he decided to just shut down Altern, rendering the 47,000 websites he hosted unavailable.

The "Altern Affair" thus became a symbol of Internet censorship in France, mobilising a small digital rights activist milieu that had been in formation in the previous years. This 
activist scene was comprised of a handful of organisations with strong overlaps with each other: Along with Altern, other hosting providers like R@S and Globenet - both founded in 1995 and focused on helping activist groups fighting for social justice "get online" by setting up email servers, mailing lists and websites - rose to prominence. They were complemented by the French Data Network (FDN), a non-profit Internet access provider created in 1992 and still in operation today. When these alternative infrastructures became threatened by the growing commodification of the Internet and the state's first attempts at enacting specific rules to regulate Internet content, these actors turned into political advocates through the creation of the Association des Utilisateurs d'Internet (AUI) and later of IRIS (“Imaginons un Réseau Internet Solidaire"), some of France's first non-profits focused on the political and legal defence of human rights online, founded in 1996 and 1997 respectively.

In this article, we seek to revisit the 1990s as a foundational moment for digital rights activism, a sub-field of media activism committed to fostering emancipatory uses of the Internet and making the digital infrastructure an object of political struggle. Focusing on France, our socio-genesis looks at the historical conditions that allowed a small group of computer scientists, programmers and hackers to wield significant influence over the Internet's political economy and policies. Through archival work, interviews with key activists and building on existing French literature, this article blends historical, sociological, and policy analysis to trace the politicisation of these individuals endowed with technical skills who came to play a central role in the advent and the political defence of an "alternative Internet," where alternativeness is usually a measured by the "distance from the centres of state and capital" (Tréguer, Antoniadis, \& Söderberg, 2016) and the ability of such socio-technical arrangements to challenge "established relations of authority and control" (Bailey, Cammaert, \& Carpentier, 2007). While doing 
so, we also aim to highlight internal divisions that laid bare during the movement's phase of emergence, divisions which would play a role in its weakening in the early 2000s.

Of course, the story that we narrate here needs to be situated in a global context: The 1990s saw the first large-scale government attempts at controlling the Internet, a then new and increasingly popular communication medium. In reaction, many countries saw the crystallisation of activist milieus that sought defend the rights of Internet users and the emancipatory potential of the Internet. Within these broader international trends, our goal is to highlight the specificities of the French situation. In this way, we hope to complement existing accounts of the history of digital rights activism - one that has long been dominated by Anglo-Saxon countries (Coleman, 2012; Tim Jordan \& Taylor, 2004; Timothy Jordan, 2016; Levy, 1984, 2001; Postigo, 2012; Sauter, 2014) - and contribute to the growing body literature focusing documenting European histories of the field (e.g. Bazzichelli, 2009; Lovink, 2009; Löblich \& Wendelin, 2012; Burkart, 2014; Milan, 2013; Denker, 2014; Nevejan \& Badenoch, 2014; Medosch, 2015; Fornés, Herran, \& Duque, 2017). At a broader level, the article reflects on the changing tensions and factors that shape the digital rights field, and through it the multi-faceted macrotechnical system we call the Internet.

\section{Setting the French scene}

The role played by France's first digital rights advocates can only be understood by retracing their unique trajectories in the field of computing. Even though there were differences in terms of age, background or status in the field of computing - some selfdesignated as hackers or pirates, others as computer programmers or "sysadmins" -, their life history often followed similar patterns. In many respects, they were what 
France had closest to a public "hacker scene."

\subsection{Kiddies enter the professional computer field}

Like Valentin Lacambre, most of those who would take an active part in the origins of French digital rights activism - mostly young white males coming from rather privileged, middle-class families - discovered computer networks as youngsters in the 1980s. Whether on closed switched telephone networks like the Minitel, Calvacom or, later on, the more open Usenet, they had first-hand experience of these online fora where they socialised by sharing knowledge, educational material and technical skills (interview 2).

As they graduated from school and transitioned to the job market, these young computer programmers quickly realised that their approach to computing was a distinctive one. Indeed, they were the first "personal computer (PC) natives." As underlined by Laurent Chemla - who in 1996, at the age of 32, co-founded the Association des Utilisateurs d'Internet (AUI), France's first digital rights organisation -, the arrival of this new generation was a "total disruption" (interview 1). Whereas the "old guard" had been trained at "data processing", using large systems in a corporate world undergoing computerisation, the geeky avant-garde had an agile, almost creative relationship to PCs. According to Chemla:

"When asked by their workmates to do something, they were used to saying 'no.' It was a very, very closed milieu, and here comes micro-computing where all of a sudden, a whole generation of kids starts making the things they were doing, only better, faster, and much more cheaply. And instead of saying 'no,' the kids say 'sure, that should be possible'."

These young competitors broke traditional hierarchies in the computer field. Though they had university degrees, they attended less prestigious universities than those of the 
"data processors" who were graduates from France's top elite schools. It was still a time when computers came with their schematic diagrams, and programming languages, such as BASIC, were simple enough that those who were committed could just pick it up. Benjamin Bayart - a computer engineer born in 1973 who in 1997 became the president of French Data Network (FDN), a non-profit Internet access provider still in operation today - summed it up in this way: "Alone in your room, you could learn to program Tetris" (interview 1). In this particular moment of the history of computing, these individuals grew up to be perceived as self-taught "computer geniuses." A label that stuck with them and probably gave them the confidence to become something more than just skilled techies.

\subsection{An apolitical scene}

Unlike in other countries where some hackers claimed a political stance, these French Internet pioneers did yet not think of themselves as political. They typically had no direct experience with policy, much less activism,. This generation was too young to have participated to the free radio endeavours of the 1970s. They largely ignored the first experiments at setting up online alternative media anchored in social movements like philosopher Félix Guattari, who in 1986 and with the help of the computer scientist Edgar Blaustein set up the 3615 Alter, a Minitel service that aggregated and broadcast news while offering forum-like features for activist groups (Prince \& Videcoq, 2005); or Samizdat, an autonomous-anarchist Bulletin Board System (BBS) that was set up in France with the help of Italian comrades from the European Counter Network (Papatheorodou, 2005).

Even for those who indulged in illegal activities - and in contrast to North-American hackers (Coleman, 2016) - the direct experience of repression did not spark 
politicisation. In 1986, at the age of 22, Laurent Chemla worked in small company where he programmed a piece of software used by schools to set up their own Minitel portals. On the side, he was also developing his hacking skills by entering computer systems. One day, he got onto the unsecure Minitel server of France's leading coffee brand, Cafés Grand'mère. After using the company's messaging system for himself, he shared the good news with fellow hackers. The Direction de la Surveillance du Territoire (DST) - France's domestic intelligence agency - worked the case, putting Chemla and one of his friends under surveillance for two months and eventually arresting them. Detained during two days, Chemla was charged with "electricity theft," as France lawmakers had yet to adopt criminal provision against "computer fraud." He was eventually acquitted, the judge holding that it was the company's responsibility to secure its servers.

Chemla, acting on his own, was exploring for fun and was not part of what is often referred to as the "hacker underground". In France, there was also an active scene of underground hackers breaking into systems with a number of them apprehended by state authorities. But unlike in the US, Germany or Italy, the French underground scene never got organised. It retained a very loose structure and did not boast overt political goals. In part, this can be seen as the result of the infiltration by intelligence agencies who, in different ways, pressured young French hackers fearful of prosecution into working for them (Guisnel, 1995; Tréguer, 2017).

\section{Becoming Alternative Internet Service Providers}

The political convictions forged by the French Internet pioneers came to the fore in the first half of the 1990s. According to them, it grew out of Usenet. Usenet was perceived as an implicit anarchist space with no formal structure of authority (interviews 1) - a 
feature that was the result of sustained struggles among Usenet's designers

(Pfaffenberger, 1996). The joys and wonders of these open networks - first Usenet, and then the Internet - needed to be spread.

\subsection{The activist connection: Building the "free and non-profit" Internet}

In 1992, FDN, one of France's very first publicly available Usenet access provider - and soon Internet access provider - was created. Two years later, it counted dozens of nonprofits among its 400-strong membership. After bridging the Minitel with Usenet and the Internet, Lacambre set up the web hosting provider Altern in 1994, which also gathered many non-profit among its users. In February 1995, Globenet was created to supply various online services and Internet access provision to activist groups working for social justice, with the support of international networks tied to the Association for Progressive Communication (APC).

The last months of 1995 were a turning point. In the Fall of that year, a vast government overhaul of the pension scheme sparked one of the biggest mobilisations in the country's modern history. Strikes paralysed the railways and the postal network. Through François Sauterey, a friend who had connections with socialist groups and trade unions, Laurent Chemla and Stéphane Bortzmeyer helped unionised postal service workers connect one of their old computers - nicknamed "Emiliano" in reference to the Zappatista rebellion in Chiapas - to the Internet (Granjon \& Torres, 2012). This ensured the ability of mobilised groups to coordinate via email and newsgroups, marking the creation of the so-called Réseau Associatif et Syndical (R@S): To make the initiative sustainable, R@S was registered as a non-profit a few weeks later, with Sauterey as president and de facto Chief Technology Officer. For several years, it would equip trade unions, journalist organisations, anti-racist or feminist groups as well as many others 
with websites, mailing lists and email accounts, free software being a vital component of this infrastructure.

Thanks to these various non-profit infrastructure providers relying on the voluntary contribution of a few isolated and trusted individuals, the country thus saw the formation of a self-proclaimed "free and non-profit Internet" sector ("Internet libre et non-marchand") that helped synchronise online mobilisations and allowed these various groups to coordinate. In November 1998, during the "Congress of the non-profit Internet," representatives of various activist groups offered the following assessment of this first experience:

"The Internet is first used for traditional activist actions. It is used as an affordable publication venue, lowering the cost of communication between activists and, beyond that, allowing people and organisation to make contact that would otherwise not be easy to establish.

In parallel to this use, the Internet can represent a new means of struggle. Thus, the action of associations like Attac (Association for the Taxation of financial Transactions and Citizen's Action) and Glb (Gays and Lesbians connected) is structured with and around the Internet, and would have taken a very different form without the use of this tool" (IRIS, 1998).

\subsection{Market connections: Subverting or cashing in?}

To a large extent, these efforts aimed at getting these activist groups online was a conscious attempt on the part of techies to ensure that the recent wave of commodification would not wipe out the Internet's original ethos of free expression and sharing (interview 5). Naturally, these initiatives were very much dependent on the voluntary work of a handful of individuals. FDN, the non-profit access provider, was running thanks three second-hand NEXT computers and modems installed in the Parisian living room of one of its co-founder, Christian Paulus (Trudel \& Tréguer, 
2016). With this small infrastructure and no employees, FDN was still among the twenty largest Internet access providers in terms of market share in 1995 (Rebillard, 2012). In this foundational moment of the digital economy, in a booming but still fragmented market, small non-profit actors still had weight.

Although some of them like Bortzmeyer were working in the public sector, others were also marketing their skills to some of the rising players of the French digital economy. By 1995, FDN's co-founders - who today pride themselves with being the first access providers to offer a flat-rate subscription model (interview 3) - left the group to pursue their careers in the booming tech sector (today, one of them currently works at Orange Telecom, another moved to California soon after the launch of FDN is now director of engineering at Google). Through a small company called Brainstorm, Chemla and his associates were building the "connexion kit" of Club Internet, a commercial Internet access provider (interview 1). Christophe Wolfhugel, vice-president of the AUI, was cofounder of Oléane, the first for-profit company providing Internet access to businesses across the country. By 1998, it was France's second largest Internet access provider with 50 employees and 50 million francs ( $€ 7,7$ million) in revenue, and the same year was bought by France Télécom (Deblock, 2008).

Some, like Lacambre with his 3615 Internet, also developed strategies to make business contribute to the sustainability of an Internet commons open to all, free of charge - in that case Altern. Later on, in 2000, with Chemla and two other associates, Lacambre also created Gandi, a domain name registrar that aimed at "breaking the domain name market," with the firm conviction that domain names should be treated as public goods and made available as cheaply as possible (Chemla, 2002). Gandi was an immediate business success and helped fund many alternative providers. But eventually, Lacambre 
and Chemla were forced to leave the company over a disagreement with the two other founders who thought this approach hindered the development of the business (Fievet $\&$ Manach, 2006).

\section{Turning Into Digital Rights Advocates}

These digital pioneers, straddling the line between advocacy and business, therefore held key positions to define and direct nascent Internet policy.

\subsection{First debates on Internet intermediary liability}

In February 1995, France's “Internet pioneers" faced a worsening situation, with a first crackdown on encryption on the part of the government (Tréguer, 2017) and an increasingly hostile media coverage focusing on the alleged "lawlessness" of the Internet.

On the Usenet group fr.network.divers, someone floated the idea of creating a non-profit focused on Internet users ('Association usagers de l'Internet', 1995). Discussions lasted for a year and eventually led to the creation of the AUI in February 1996, an volunteerrun organisation. Among this group, Meryem Marzouki - a young computer scientist brought up under Ben Ali’s dictatorship in Tunisia who worked at CNRS, France's national research center - was elected director of the group, while Laurent Chemla and Isabelle Saint-Saëns - a social science researcher and activist born in 1948 who took part in the May 1968 protests - both served as deputy directors. They were joined in the board by Stéphane Bortzmeyer, treasurer, Christophe Wolfhugel - another computer scientist - as secretary of the organisation ('AUI - Historique et Fondateurs', 2001).

That same year, as elsewhere in Europe and Northern America, many cases would be brought before French courts against Internet access providers, accused of being 
accomplices of hate speech or child abuse just because their users had accessed such content (Schafer, 2018). In June 1996, in a sudden attempt to establish clear rules regulating online freedom of expression and allegedly shield Internet intermediaries from litigation, the right-wing government - represented by the young minister in charge of telecommunications, François Fillon - tabled an amendment to the bill making its way through Parliament to privatise French incumbent telecom operator, France Télécom.

The amendment sought to re-establish the censorship system set up to regulate the Minitel (Mailland \& Driscoll, 2017). According to Fillon's proposal, the Conseil Supérieur de l'Audiovisuel (CSA) - the state agency in charge of regulating broadcast media - would host a new committee tasked with drafting a "deontology code" for online services. Anybody could then report websites and other online services found in violation of the code, a procedure that would then lead the committee to issue an opinion on the matter at hand. In case of "negative opinion" confirming a violation of the code, Internet access providers would have to block access to the targeted service, or else risk being found liable of the offence. Rather than placing the regulation of online speech under the authority of the judiciary, as provided in the 1881 Law on the freedom of the press, the "Fillon amendment" established an extra-judicial censorship regime.

Against those criticising a liberty-killing provision showing the French state's longstanding disregard for freedom of expression, the minister even took the initiative of going on Usenet to defend its proposal ('Amendement Fillon', 1996). But despite opposition from a number of lawmakers, the amendment was adopted. It would mark the first full-fledged campaign for the newly-formed AUI. According to Chemla:

"We were less than a dozen, and for the most part had never had any political activity (...). We started an intense work of telephone lobbying with the help of 
other novice activists, which managed to convince sixty Members of Parliament from the Socialist Party to refer the bill to the Constitutional Council" (Manach, Girardeau, \& boyd, 2010).

Valérie Sedallian, a young lawyer who had joined the ranks of AUI even contributed to writing the brief. The Constitutional Council eventually struck down the provision, arguing that freedom of expression, protected at Article 11 of the 1789 Declaration of the Man and of the Citizen, deserved appropriate safeguards which were lacking. The first campaign of the AUI was thus successful, giving France's first digital rights advocates a boost of confidence : As Chemla puts it, "just a few of us took the responsibility to influence the direction of society as whole, and one of the highest authorities proved us right" (Chemla, 2002).

Indeed, the position defended by AUI members seemed rather marginal at first. Even large corporate providers, represented by the AFPI - the Association française des professionels de l'Internet-, approved the provision. But now there were forced to admit that the Council had a point (Mauriac, 1996). The corporate position reflected their primary focus on overcoming an antiquated legal framework that created strong legal risk for the development of their business, and a way to shield themselves from the litigious activities of their users. Due to the Council's ruling, commercial providers were forced to start adjusting their stance to that of digital rights activists.

After the failure of the Fillon amendment, the debate on intermediary liability moved to a special committee created by the government - the so-called Beaussant committee, named after the president of the commission, also head of an industry group representing online media. The mandate of the committee, comprised of 88 members, was to establish mechanisms for so-called "self-regulation" to implement French laws on public speech.- an approach attuned to the neo-liberal spirit of the time then 
promoted at the global level for Internet governance.

After having managed to get a seat at the committee's table, the main task for the AUI in these discussions would be to advocate the trust economy that dominated the early-days of the Internet, known as the "netiquette" (Hambridge, 1995). These were the forms of self-regulation that had worked so well for the Net's first users, but they were now being undermined by the diversification of Internet-users and the medium's growing commercialisation. In this context, the pioneers needed to make the customary laws explicit to preserve a space that they cherished, and of which they were the selfproclaimed stewards and guardians. As Nicolas Auray has shown (2012), French digital rights activists rejected both market mechanisms grounded in contract law and the state's authoritarian approaches to Internet regulation. Instead, they aimed for the "moral institution" of Internet users through the netiquette, whereby judicial authorities would act as ultimate referees in interpreting the right-respecting "laws of the Republic," as provided by the 1881 press law.

But in February 1997, AUI members withdrew from the Beaussant committee. They announced their decision during a press conference, citing the lopsided representation of the committee, which heavily favoured industry players. The latter's proposed "Internet Charter" came down to imposing contractual rules onto intermediaries, effectively pushing them to police the speech of their users ("AUI - "Charte de l'Internet", 1997). By leaving the committee, AUI undermined the legitimacy of the committee, which in turn delayed the adoption of joint recommendations. They actually never saw the light of day: In an unexpected turn of events, the legislative elections called for by the French President Jacques Chirac led to the unforeseen victory of a left-leaning coalition, headed by Lionel Jospin. The change in government meant that the Beaussant committee was 
effectively dead. But the crucial question of the legal status of intermediaries still lacked a substantial answer, not only at the French level but also in Brussels where European lawmakers were starting to work on EU-wide rules on the matter.

\subsection{Alternative providers become a target: The Altern Affair}

In 1997, Altern was one of the biggest hosting providers in France. Not only was it free of charge, but it also had no advertising and was open no anyone - not just activist groups, which set Altern apart from other non-profit hosting providers like R@S and Samizdat (although its model was replicated by another hosting service created in 1996 which sold out to a larger commercial player the next year: mygale.org, see Trédan, 2014). As a single-person organisation, Altern epitomised the possibility of creating low-cost, non-commercial Internet services that rivalled for-profit alternatives. It also made it an easy target for those willing to re-establish law and order on what many saw as an untamed social space.

After the first trials involving Internet access provider in early 1996 (Schafer, 2018), a consensus that these actors ought to play a neutral role in the transmission of content formed So the debate quickly refocused on the next intermediary in line: Hosting providers.

Several commercial hosting providers were already adopting contractual rules that gave them the right to take-down "illegal content" posted by their users upon being notified. That meant that commercial providers were already starting to play the role of private censors. For Lacambre, such policies were unacceptable. Even though he had already taken down websites on Altern, he refused to make these exceptional interventions an

official policy. That and the fact that the service was open to anyone, without any formal subscription (which gave users and observers an illusion of anonymity), made Altern an 
easy target for those concerned about the spread of unfiltered online speech. So from May 1997 on, the thirty-something Valentin Lacambre would repeatedly be summoned in court, facing no less than 15 cases over the next three years, two of which led to actual sentences.

It is one of these sentences that led to the shut-down of Altern. Nude pictures of the model Estelle Halliday published in the press ended up on the website of one of Altern's users, only identified by his pseudonym Silversurfer. When Halliday's lawyers went to court alleging a breach to the right to the protection of her image, Lacambre was the only one assigned. He argued - unsuccessfully - that the plaintiffs should have targeted the website's owner, who could be identified by some of the logs that Lacambre had kept (for all their defence of encryption as necessary for the protection of the confidentiality of communications, the right to anonymity was not high on the French activists' agenda at the time). The charge was relatively modest, but Lacambre knew that these trials touched on crucial, unresolved issue that the AUI and others had been struggling to solve. So he appealed the decision.

Retrospectively, this proved to be an ill-advised move, as the court of appeal proved to be much harsher. On February $10^{\text {th }}, 1999$, it found that Lacambre, by helping others to "communicate anonymously," had exceeded "the technical role of a mere transmitter of information" and was therefore liable. The ruling pushed Lacambre to play the role of a censor, systematically checking the content posted by its users. At a practical level, this was just impossible. Screening the content and updates of more than 47,000 websites could not be automated - at least not in the late 1990s. In a interview given to the newspaper Libération a few days after the ruling, Lacambre explained that in order to screen the two million document stored on Altern plus the ten thousand uploaded each 
day, "I would need to hire a thousand people for six months" (Dufresne \& Latrive, 1999).

Among digital rights activists, the ruling was received as a blow. All the more considering that it came a few weeks after the police of Rennes had raided a non-profit hosting provider known as "The Village," arresting its system administrator on copyright grounds to stop the dissemination of an horror film posted by one of its users (Schafer, 2018). The Altern ruling was the straw that broke the camel's back. Lacambre's conviction effectively meant that only large actors, with enough financial power to sustain legal challenges, could become hosting provider. In that regard, the ruling paved the way for the centralisation of the network and hurt the efforts of much of non-profit alternative hosting providers, but also of small commercial providers.

The "Altern Affair" led to the first large-scale mobilisation of digital rights activists and growing number of politicised Internet users. A collective of "independent webmasters" united under an initiative called "minirézo" published a manifesto. Whereas the rather pro-market US cyberlibertarians had declared the independence of "cyberspace" a couple of years earlier (Barlow, 1996), the French activists aimed to defend the "Independent Web" against a rising tide of state control and commodification:

"The Independent Web is found in these millions of websites offering millions of pages made of of passion, of opinion, or information, put in place by users aware of their role as citizens. The Independent Web is a new link between individuals, a place where knowledge is exchanged on a free and open basis (...). [It] offers a free vision of the world, bypassing the economic censorship of information, its confusion with adversing and infomercial, its reduction to a stupefying and manipulative spectacle" (minirézo, 1999).

Political elites reacted to the Altern ruling and the ensuing mobilisation by expressing their support. Dominique Strauss-Kahn, minister of the Economy in the Jospin 
government, wrote to Lacambre and made clear that for him, "the host of websites [could not] be compared to a press publisher or a television channel," hinting at the fact that new rules needed to be found (Strass-Kahn, 1999).

The following month, in March 1999, the Jospin government was organising the “celebration of the Internet" ("fête de l'Internet"), an event aimed at popularising Internet use across France. In an act of protest against state censorship, more than 1300 websites responding to the call of minirézo shut down for three days. Chemla and other digital rights activists put together a website to relay this "Web blackout" campaign, entitled "the Defeat of the Internet" ('Défaite de l'Internet', 1999). In his speech opening the event, Prime Minister Lionel Jospin admitted that new rules would have to be found, citing ongoing negotiations in Brussels on this issue (Jospin, 1999).

\subsection{Geeks rule}

The adoption of these "new rules" materialised a few months later France with an amendment presented by Patrick Bloche, a socialist MP, in charge of a bill reforming the French audiovisual sector. In its first version, the amendment established exactly what the digital rights activists had hoped for: A judicial oversight over online speech. A host's failure to comply with a judicial decision ordering the takedown of an illegal was the only event in which it could have found liable. But later during the legislative debate, Bloch backtracked. The amendment was changed again to condition the liability exemption to the prior identification of all users, and to the respect of "due diligence" when the intermediary was notified by a third-party of the existence of litigious content on its servers. The notion of "due diligence" implied that the intermediary ought to act on its own initiative to take the reported content down, which amounted to private censorship. But because of the lack of safeguards, the provision was again struck down 
in June 2000 by the Constitutional Council, which re-established the initial version of the amendment. At the same moment in Brussels, EU lawmakers were adopting the directive on the Information Society (also nicknamed the eCommerce directive) which, despite ambiguities, also provided liability exemptions for internet intermediaries.

At the turn of the millennium, a fragile compromise was finally reached on the complex issue of online intermediaries, and their role with respect to the fundamental rights of Internet users. Despite the reluctance of important industry sectors and state officials, that compromise was aligned with the stance of digital rights activists, and had been sanctioned on two occasions by the Constitutional Court. Not only that, but these activists were also winning in their long-standing opposition to France's rigid rules on the use of encryption software (Sedallian, 1998; Warusfel, 2000). By combining technical expertise, disruptive models for the provision of alternative Internet services, by building on hackers' special ability to learn the language of the law (Coleman, 2012, 2016) -, but also by collaborating with other activists and lawyers to uphold fundamental rights in the digital world, a handful of French techies had become the leading "citizen voice" on Internet politics.

Their influence was also felt at the Europe and globally thanks to Meryem Marzouki. First as president of AUI, she had become an important participant of the Global Internet Liberty Campaign (GILC) - a global network of digital rights activist formed in June 1996 with the support of the Open Society Institute. In June 1997, she represented the campaign in an address to diplomats at the Organisation for Economic Co-operation and Development (OECD) (Marzouki, 1997). In 2002, she would also play an instrumental role in the creation of European Digital Rights (EDRi), a European offshoot of the GILC. Thanks to her, that small French activist milieu who had largely 
worked in isolation from their counterparts in other countries found itself connected to global networks.

\section{The Weakening of a Movement}

From 2000 on, with the burst of the dotcom bubble and the terrorist attacks of 9/11, Internet politics entered a new phase. In France, it would coincide with the waning of the movement's influence. A combination of endogenous factors explain this new state of play.

\subsection{Losing ground: The shrinking membership of alternative providers}

Already in December 2000, during the third "Congress of the non-commercial Internet," there was a shared understanding that it was getting harder for activists to stay on the

edge and remain competitive against a now flourishing digital economy:

"Overall growth in demand has been strong and has mechanically expanded the potential of 'alternative providers': the culture and use of the internet is reaching layers of society that are still in minority, but their represent larger segments of the population, associations, parties and unions.

However the qualitative offer of the commercial sector has evolved a lot: access and "free" hosting, unlimited connection (or almost!), broadband via ADSL or cable etc., start of the WAP and online television, creation of portals and brand effects. Each of these developments raises new questions for the non-profit sector, its objectives, its resources, its mode of financing, operation and development, and its visibility” ('Troisièmes Assises de l'Internet non marchand et solidaire', 2000)

This growing sophistication of online commercial services had another effect: Altering the relationship between users and alternative providers. According to Sauterey, of the $\mathrm{R} @ \mathrm{~S}$, "we were getting at a point where it was getting a little tense with our members who were becoming more and more not just members but users, leading to mercantile customer-to-business relationships" (interview 5). 
For many activist groups who had relied on alternative providers in the second half of the 1990s, the convenience of commercial services was irresistible. Dial-up Internet access providers like FDN and Globenet saw their membership base shrink drastically in a few years, as the ADSL market boomed (in 2005 , FDN was left with only 40 member-subscribers, compared to half-a-thousand a decade earlier, and those who stayed were mainly motivated by the technical thrill of operating the service). Hosting providers like R@S saw many of their members moving to commercial providers with state-of-the art equipment with easy-to-use interfaces and graphical features. . According to Marzouki and Sauterey, from the mid-2000s on, with the wave of "Web 2.0" services, activist groups that were part of the movement for global justice felt like their audiences could be reached more easily on commercial platforms. In the costbenefit analysis, the control over the communication infrastructure did not seem all that important - a trend that has been observed in other contexts (e.g. Uldam \& Askanius, 2011; Terranova \& Donovan, 2013; Klang \& Madison, 2016).

\subsection{The plague of "Internet -centrism"}

The weakening of non-profit providers - and the corollary atrophy of their political muscle - was connected to another hurdle: Disagreements over the political identity of the movement, and the political understanding of the Internet.

Looking back at the period, our interviewees expressed frustration regarding the readiness of other activist milieus to move to commercial alternatives, which they attribute to a limited understanding of the Internet. "I don't think that anti-globalization activists were aware of the what the Internet is and the kind of political questions that it raises", Bayart explained. "[the] Internet was seen as a tool, not as a militant act" (interview 1). Some might argue that here is another instance of "Internet-centrism," a 
propensity to see social change through the prism of the Internet (Morozov, 2013). But the point reflects the shared feeling that a thorough understanding of the political issues specific to Internet policy was never fully appropriated by the activist groups that techies were working for. As Sauterey acknowledges regarding the founding of the R@S, “without Stéphane [Bortzmeyer] and his defense of Linux, I don’t think we would have go down that path" (quoted in Granjon \& Torres, 2012).

Conversely, despite the political acculturation reported by people like Chemla as they worked with trade unions and global justice activists, techies often failed to put Internet politics in a wider political context. Commenting on the founding of AUI, Meryem Marzouki stressed that for many of its members, the main goal was "the growth of the number of people connected to the Internet period, whatever the means used" (interview 6). A fact that Chemla also acknowledged:

"I have always said that we would win when the mass of [Internet] users got large enough to appropriate the tool, so that going back to the way it was before would be impossible. In a way I was optimistic, because despite the huge mass of users, the resources facing us today have also become gigantic" (interview 1).

According to this Internet-centrist view, the spread of Internet technologies was in and of itself a positive development that would have political consequences at the macro level. But for Marzouki and others, "that wasn't the idea." For them, “the Internet itself was never the goal (...). The reason why the Internet matters is what it allows us to do. What I'm interested in is not the development of the Internet for its own sake. It is a particular Internet that we were interested in, a certain way of developing it" (interview $6)$.

Part of these political disagreements might be exaggerated. Or at least, they seem exacerbated by the actors' different social positions at this crucial moment of the 
formation of the movement - and in particular their relationship to the corporate world. In the first section, we offered a general overview of the trajectory of some influential techies, but a detailed prosopography would probably help refine our understanding of these disagreements, which had also a personal dimension. What we do know is that Marzouki and a few other AUI members eventually left AUI in 1997 to start another similar organisation, IRIS, which would take the lead on French digital rights advocacy until the mid-2000s and worked closely with the R@S, its members, as well as European and global digital rights networks. IRIS was a way for Marzouki to ensure that a critical political approach to the Internet grounded in the political left could develop. "Our vision of the Internet was included in the wider frame of our vision of the social world, of the economy, of society, our political vision." IRIS, fuelled by Marzouki's work, slowly withered in the second half of the 2000s, before a new French digital right organization - La Quadrature du Net - emerged. At this point, around 2009, the movement as a whole was undergoing a sort of revival across Europe.

\section{Conclusion}

Twenty years after the birth of digital rights activism, online communications have been absorbed by multinational infrastructure providers - mostly US tech companies - that top the world's biggest market capitalisations. These companies monitor the activity of their users to build user-profiles they sell to advertisers while regulating online speech based on vague provisions inscribed in their terms of services. States also readily make use of these company's data troves to develop sophisticated propaganda techniques and boost their own surveillance capacities, while pushing for the expansion of private censorship. Much of these efforts involve the development of filtering tools based on so-called "Machine Learning" techniques that aim to automate content take-downs, but 
also the work of tens of thousands of subcontractors in low-wages countries (Roberts, 2016; Casilli, 2016). Privacy and freedom of expression online are thus increasingly subject to a form of public-private "hybrid rule" (Hurt \& Lipschutz, 2015) that escapes judicial oversight and democratic accountability.

The new political reality of the Internet may lead to harsh judgements against digital rights activism. As a matter of fact, many of our interviewees expressed mixed feelings of pride and regrets for having failed to sustain the magic of the 1990s, and disenchantment about the evolution of the Internet's political economy. Their retrospective look at this early phase, however, gives us a better sense of the movements' successes, of its dead angles and their relation to a given historical context, of its inability to manage some of the contradictions that gave it strength before undermining its cohesion and influence, of the state's refusal to actively support alternative providers who achieved impressive results with very little resources. It also speaks to the importance of sustaining a dynamic alternative Internet sector and its connection to digital rights advocacy, but also the need to ground the later in a systemic, collective approach to empowerment that wards off a tendency to Internet centrism and technical solutionism.

\section{Funding}

This work was funded by Agence Nationale de la Recherche (UTIC project ANR14-CE28-0024) and Horizon 2020 Framework Programme (netCommons project $\left.n^{\circ} 688768\right)$. 


\section{Interviews}

Interview 1 : Bayart, B and Chemla, L. (2016, July 15). Interview by Félix Tréguer and Camille Paloque-Bergès [Face-to-face].

Interview 2: Paulus, C. (2016, October 19). Interview by Félix Tréguer and Dominique Trudel [Telephone]

Interview 3: Nicaise, J.-P. (2016, October 27). Interview by Félix Tréguer [Telephone] Interview 4 : Lunar, (2017, June 22). Interview by Patrick Pétin [Face-to-face].

Interview 5 : Sauterey, F (2017, November 13). Interview by Patrick Pétin [Face-toface].

Interview 6 : Marzouki, M (2017, October 4). Interview by Patrick Pétin [Face-to-face].

\section{References}

Amendement Fillon. (1996, June). [Usenet archive]. Retrieved 29 March 2018, from https://groups.google.com/forum/?hl=fr\#!topic/fr.soc.divers/GKmAu8w1M9w Association usagers de l'Internet. (1995). [Archives Usenet]. Retrieved 27 April 2017, from https://groups.google.com/forum/\#! searchin/fr.network.divers/Association\$20usagers\$20de\$201\$27Internet| sort:relevance/fr.network.divers/ocqMSlhTywU/I3bWVEKzTe4J

AUI - 'Charte de l'Internet' - Communique de presse du 05/03/97. (1997, March).

[Usenet archive]. Retrieved 29 March 2018, from https://groups.google.com/forum/\#!topic/fr.misc.droit/zgsYArfSdz4

AUI - Historique et Fondateurs. (2001, July). [Archives]. Retrieved 27 April 2017, from https://web.archive.org/web/20010702104200/http://www.aui.fr:80/Textes/historiqu e.html 
Auray, N. (2012). L'Olympe de l'internet français et sa conception de la loi civile. Les Cahiers du numérique, 3(2), 79-90.

Bailey, O. G., Cammaert, B., \& Carpentier, N. (2007). Series Editor's Foreword. In Understanding Alternative Media (pp. ix-x). Maidenhead: Open University Press/McGraw-Hill.

Bazzichelli, T. (2009). Networking: The Net as Artwork. BoD - Books on Demand. Burkart, P. (2014). Pirate Politics: The New Information Policy Contests. Cambridge, Mass: The MIT Press.

Casilli, A. (2016, November 20). Never mind the algorithms: the role of click farms and exploited digital labor in Trump's election. Retrieved 28 March 2018, from http://www.casilli.fr/2016/11/20/never-mind-the-algorithms-the-role-of-exploiteddigital-labor-and-global-click-farms-in-trumps-election/

Chemla, L. (2002). Confessions d'un voleur : Internet, la liberté confisquée. Denoël.

Coleman, G. (2012). Coding Freedom: The Ethics and Aesthetics of Hacking. Princeton University Press.

Coleman, G. (2016). From Internet Farming to Weapons of the Geek. Current Anthropology, 58(15).

Deblock, F. (2008, October 7). Première success story : Oléane. Retrieved 23 March 2018, from https://www.journaldunet.com/solutions/systemesreseaux/interview/jean-michel-planche-un-entrepreneur-reconciliant-ambition-etvaleurs/premiere-success-story-oleane.shtml

Défaite de l'Internet. (1999, May 8). Retrieved 26 March 2018, from https://web.archive.org/web/19990508211551/http://www.defaiteinternet.org/DEFAITE/defaite.shtml 
Denker, K. (2014). Heroes Yet Criminals of the German Computer Revolution. In G. Alberts \& R. Oldenziel (Eds.), Hacking Europe - From Computer Cultures to Demoscenes (pp. 167-188). Springer.

Dufresne, D., \& Latrive, F. (1999, February 23). Valentin Lacambre arrête les frais. Selon lui, plus qu'Altern, c'est la libre expression qui est menacée. Libération. Retrieved from http://www.liberation.fr/medias/1999/02/23/valentin-lacambrearrete-les-frais-selon-lui-plus-qu-altern-c-est-la-libre-expression-qui-estmenace_265733

Fievet, C., \& Manach, J.-M. (2006, June 29). Entretien avec Valentin Lacambre et Laurent Chemla. Retrieved 29 March 2018, from http://www.internetactu.net/2005/06/29/entretien-avec-valentin-lacambre-et-laurentchemla/

Fornés, J., Herran, N., \& Duque, L. (2017). Computing for Democracy: The Asociación de Técnicos de Informática and the Professionalization of Computing in Spain. IEEE Annals of the History of Computing, 39(2), 30-48. https://doi.org/10.1109/MAHC.2017.13

Gerich, E. (1992). Guidelines for Management of IP Address Space. Retrieved from https://www.rfc-editor.org/rfc/rfc1366.txt

Granjon, F., \& Torres, A. (2012). R@S : la naissance d'un acteur majeur de l'« Internet militant » français. Le Temps Des Médias, 18(1), 87. https://doi.org/10.3917/tdm.018.0087

Guisnel, J. (1995). Guerres dans le cyberespace : services secrets et Internet. Paris: La Découverte.

Hambridge, S. (1995). Netiquette Guidelines (Request For Comments No. 1855). IETF. Retrieved from https://www.ietf.org/rfc/rfc1855.txt 
Hurt, S., \& Lipschutz, R. (Eds.). (2015). Hybrid Rule and State Formation: PublicPrivate Power in the 21st Century (1 edition). Routledge.

IRIS. (1998, November 18). Compte-rendu des premières Assises de l'Internet non marchand et solidaire. Retrieved 23 March 2018, from https://web.archive.org/web/19991010011804/http://www.iris.sgdg.org:80/lesiris/li5.html\#III-1

Jordan, Tim, \& Taylor, P. (2004). Hacktivism and Cyberwars: Rebels with a Cause? Routledge.

Jordan, Timothy. (2016). A genealogy of hacking. Convergence: The International Journal of Research into New Media Technologies. Retrieved from http://con.sagepub.com/

Jospin, L. (1999). Déclaration sur le développement de la société de l'information, notamment la modernisation de l'administration, le commerce électronique et le programme d'action gouvernementale pour la société de l'information (PAGSI). In Inauguration de la fête de l'Internet. Paris. Retrieved from http://discours.viepublique.fr/notices/993000751.html

Klang, M., \& Madison, N. (2016). The domestication of online activism. First Monday, 21(6). https://doi.org/10.5210/fm.v21i6.6790

Lacambre, V. (1999). L'histoire d'altern.org. Retrieved 2 May 2017, from http://www.altern.org/alternb/defense/histoire.html

Levy, S. (1984). Hackers: Heroes of the Computer Revolution (Anv Upd). O'Reilly Media.

Levy, S. (2001). Crypto: How the Code Rebels Beat the Government Saving Privacy in the Digital Age (1st edition). London: Penguin Books. 
Löblich, M., \& Wendelin, M. (2012). ICT policy activism on a national level: Ideas, resources and strategies of German civil society in governance processes. New Media \& Society, 14(6), 899-915. https://doi.org/10.1177/1461444811432427

Lovink, G. (2009). Dynamics of Critical Internet Culture (2nd ed.). Institute of Network Cultures.

Mailland, J., \& Driscoll, K. (2017). Minitel: Welcome to the Internet. Cambridge, MA: The MIT Press.

Manach, J.-M., Girardeau, A., \& boyd, danah. (2010). La contre-histoire d'Internet. Owni. Retrieved from http://owni.fr/files/2010/12/ContreHistoire_ebook_FINAL.pdf Marzouki, M. (1997, July 2). Présentation de la coalition GILC à l'OCDE. Retrieved 30 April 2017, from http://gilc.org/speech/oecd/gilc-oecd-797-fr.html

Marzouki, M. (2003). Nouvelles modalités de la censure : le cas d'Internet en France. Le Temps Des Médias, 1(1), 148. https://doi.org/10.3917/tdm.001.0148 Mauriac, L. (1996, September 13). Les sages gênent le Net. La censure de l'amendement Fillon divise les acteurs du réseau. Retrieved 24 March 2018, from http://www.liberation.fr/ecrans/1996/09/13/les-sages-genent-le-net-la-censure-de-1amendement-fillon-divise-les-acteurs-du-reseau_182374

Medosch, A. (2015). The Rise of the Network Commons. Retrieved from http://www.thenextlayer.org/NetworkCommons

Milan, S. (2013). Social Movements and Their Technologies: Wiring Social Change. [S.1.]: Palgrave Macmillan.

minirézo. (1999, February). Manifeste du Web indépendant. Retrieved 8 June 2017, from http://archive.is/guW7 
Morozov, E. (2013). To Save Everything, Click Here: The Folly of Technological Solutionism. New York: PublicAffairs,U.S.

Nevejan, C., \& Badenoch. (2014). How Amsterdam Invented the Internet: European Networks of Significance, 1980-1995. In G. Alberts \& R. Oldenziel (Eds.), Hacking Europe - From Computer Cultures to Demoscenes (pp. 189-218). Springer.

Papatheorodou, A. (2005). Samizdat.net, l'histoire d'un projet de médias alternatifs sur Internet. Entretien avec Aris Papatheorodou. Matériaux pour l'histoire de notre temps, 79(1), 57-62. https://doi.org/10.3406/mat.2005.1043

Pfaffenberger, B. (1996). 'If I Want It, It's OK': Usenet and the (Outer) Limits of Free Speech. The Information Society, 12(4), 365-386.

Postigo, H. (2012). The Digital Rights Movement: The Role of Technology in Subverting Digital Copyright. MIT Press.

Prince, B., \& Videcoq, E. (2005). Félix Guattari et les agencements post-média. Multitudes, 21(2), 23-30. https://doi.org/10.3917/mult.021.0023

Rebillard, F. (2012). La genèse de l'offre commerciale grand public en France (19951996) : entre fourniture d'accès à l'Internet et services en ligne « propriétaires ». Le Temps Des Médias, 18(1), 65. https://doi.org/10.3917/tdm.018.0065

Roberts, S. T. (2016). Commercial content moderation: Digital laborers' dirty work. Sauter, M. (2014). The Coming Swarm: DDOS Actions, Hacktivism, and Civil Disobedience on the Internet. New York: Bloomsbury Academic.

Schafer, V. (2018). Du grand secret à la « défaite de l'Internet » : Enjeux, mobilisations et controverses autour du pouvoir des intermédiaires en France dans la décennie 1990. Histoire et informatique. 
Sedallian, V. (1998). Les problèmes posés par la législation française en matière de chiffrement. Droit de l'Informatique et Des Télécoms, (4). Retrieved from http://encryption_policies.tripod.com/france/sedallian_1098_prob.htm

Strauss-Kahn, D. (1999, February 25). Message e-mail à Monsieur Valentin Lacambre. Retrieved 26 March 2018, from https://archive.is/Cfdd0

Terranova, T., \& Donovan, J. (2013). Occupy social networks: The paradoxes of corporate social media for networked social movements. In G. Lovink \& M. Rasch (Eds.), Unlike Us Reader: Social Media Monopolies and Their Alternatives (pp. 296-311). Amsterdam: Institute of Network Cultures.

Trédan, O. (2014). Le serveur de pages personnelles Mygale. La trajectoire d'un chaînon manquant dans l'histoire de l'Internet français. Terminal. Technologie de l'information, culture \& société, (115), 31-43. https://doi.org/10.4000/terminal.244 Tréguer, F. (2017, November 2). Pouvoir et résistance dans l'espace public : une contre-histoire d'Internet (XVe-XXIe siècle) (phdthesis). EHESS - Paris. Retrieved from https://halshs.archives-ouvertes.fr/tel-01631122/document

Tréguer, F., Antoniadis, P., \& Söderberg, J. (2016). Alt. vs. Ctrl.: Editorial notes for the JoPP issue on Alternative Internets. The Journal of Peer Production, (9). Retrieved from http://peerproduction.net/issues/issue-9-alternative-internets/editorial-notes/

Troisièmes Assises de l'Internet non marchand et solidaire. (2000, December 15). Retrieved 28 March 2018, from https://web.archive.org/web/20010127001400/http://www.assises.sgdg.org:80/2000/ preparation-assises00/programme.html

Trudel, D., \& Tréguer, F. (2016). Alternative Communications Networks Throughout History (report). ISCC-CNRS. Retrieved from https://halshs.archivesouvertes.fr/halshs-01418826/document 
Uldam, J., \& Askanius, T. (2011). Online social media for radical politics: climate change activism on YouTube. International Journal of Electronic Governance, 4(12), 69-84.

Warusfel, B. (2000). Dix ans de réglementation de la cryptologie en France : du contrôle étatique à la liberté concédée. Annuaire Français de Relations Internationales, (1), $657-661$. 